\title{
Recovered recall memory after decompression of the fornix by surgical removal of pineal tumor
}

Figure 1 Pre- and postoperative (1 year) MRI
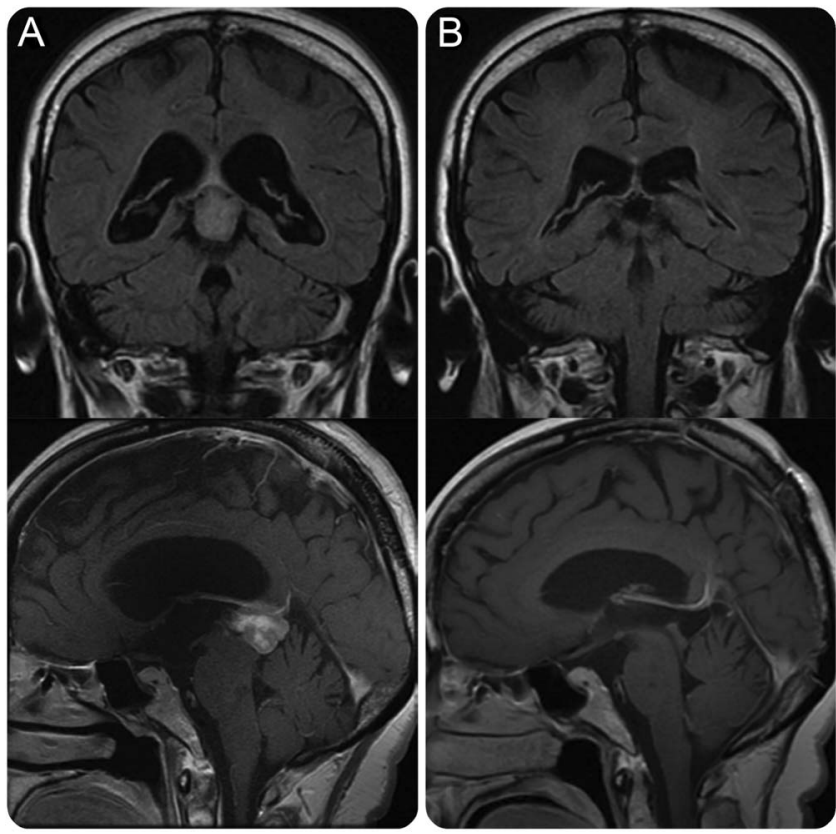

Preoperative (A) and postoperative (B) MRI. Upper panels show coronal FLAIR images and lower panels show sagittal T1-weighted MRI with Gd-DTPA (gadolinium-diethylenetriamine pentaacetic acid) enhancement. High signal intensity in the fornix shown in preoperative FLAIR image (A) is recovered postoperatively (B). FLAIR = fluid-attenuated inversion recovery.

A 45-year-old woman had a 6-month history of progressive amnesia and diplopia. At age 34, a pineal germinoma was diagnosed; whole-brain radiation induced tumor regression for 10 years. The tumor had recurred and at surgery it was detached from the fornix and resected through an occipital transtentorial approach (figure 1). The fornix was decompressed and amnesia was remarkably recovered (figure 2A).

The subtests of Wechsler Memory Scale-Revised were divided into recognition subtests and recall subtests to examine a disparity ${ }^{1}$ (figure $2 \mathrm{~B}$ ). The recognition subtests were relatively spared, even preoperatively. In contrast, the recall subtests were severely impaired preoperatively and substantially improved postoperatively. ${ }^{1,2}$

Mizuho Yoshida, MD, PhD, Toshihiro Hayashi, MD, PhD, Kurumi Fujii, MA, Kensuke Kawai, MD, PhD, Shoji Tsuji, MD, PhD, Atsushi Iwata, MD, PhD

From the Departments of Neurology (M.Y., T.H., K.F., S.T., A.I.) and Neurosurgery (K.K.), Graduate School of Medicine, The University of Tokyo; and Japan Science and Technology Agency (A.I.), PRESTO, Saitama, Japan.

Author contributions: M. Yoshida: drafting the manuscript, analysis and interpretation of data, acquisition of data. T. Hayashi: drafting/revising the manuscript, study concept and design, analysis and interpretation of data, statistical analysis. K. Fujii: analysis and interpretation of data, acquisition of data, statistical analysis. K. Kawai: revising the manuscript, interpretation of data, acquisition of data. S. Tsuji: revising the manuscript, supervision. A. Iwata: drafting/revising the manuscript, study concept and design, interpretation of data, supervision.

Study funding: No targeted funding reported.

Disclosure: The authors report no disclosures relevant to the manuscript. Go to Neurology.org for full disclosures.

Correspondence to Dr. Hayashi: thayashi-tky@umin.ac.jp

1. Tsivilis D, Vann SD, Denby C, et al. A disproportionate role for the fornix and mammillary bodies in recall versus recognition memory. Nat Neurosci 2008;11:834-842.

2. Squire LR, Wixted JT, Clark RE. Recognition memory and the medial temporal lobe: a new perspective. Nat Rev Neurosci 2007;8:872-883. 

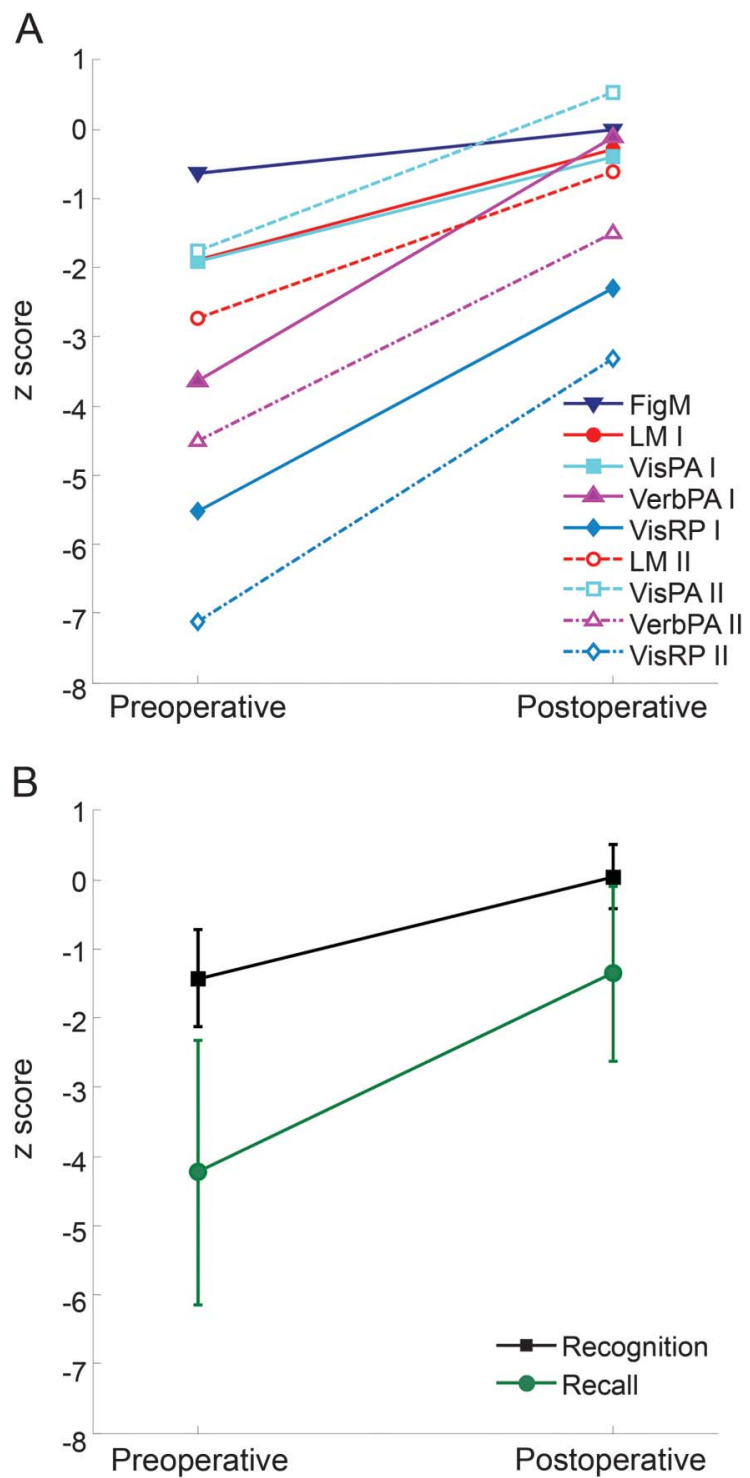

(A) The $z$ scores of the subtests. (B) Mean $z$ scores ( \pm SD) of recognition subtests (Figural Memory [FigM], Visual Paired Associates [VisPA] I/II) and recall subtests (Logical Memory [LM] I/II, Verbal Paired Associates [VerbPA] I/II, Visual Reproduction [VisRP] I/II).

\section{Save These Dates for AAN CME Opportunities!}

Mark these dates on your calendar for exciting continuing education conferences by the American Academy of Neurology. Learn more at AAN.com/conferences.

\section{AAN Annual Meeting}

- April 15-21, 2016, Vancouver, BC, Canada, Vancouver Convention Centre 


\section{Neurology}

\section{Recovered recall memory after decompression of the fornix by surgical removal of pineal tumor}

Mizuho Yoshida, Toshihiro Hayashi, Kurumi Fujii, et al.

Neurology 2016;86;790-791

DOI 10.1212/WNL.0000000000002394

This information is current as of February 22, 2016

Updated Information \& Services

References

Subspecialty Collections

Permissions \& Licensing

Reprints including high resolution figures, can be found at: http://n.neurology.org/content/86/8/790.full

This article cites 2 articles, 0 of which you can access for free at: http://n.neurology.org/content/86/8/790.full\#ref-list-1

This article, along with others on similar topics, appears in the following collection(s):

Memory

http://n.neurology.org/cgi/collection/memory

Primary brain tumor

http://n.neurology.org/cgi/collection/primary_brain_tumor Surgical therapy-tumor

http://n.neurology.org/cgi/collection/surgical_therapytumor

Information about reproducing this article in parts (figures,tables) or in its entirety can be found online at:

http://www.neurology.org/about/about_the_journal\#permissions

Information about ordering reprints can be found online:

http://n.neurology.org/subscribers/advertise

Neurology ${ }^{\circledR}$ is the official journal of the American Academy of Neurology. Published continuously since 1951, it is now a weekly with 48 issues per year. Copyright @ 2016 American Academy of Neurology. All rights reserved. Print ISSN: 0028-3878. Online ISSN: 1526-632X.

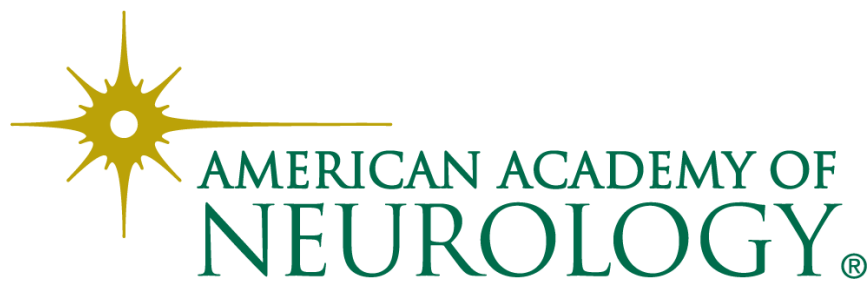

